\title{
ANALISIS PEMAHAMAN KONSEP VEKTOR PADA SISWA SEKOLAH MENENGAH ATAS
}

\author{
Witri Puspita Sari ${ }^{1}$, Eko Suyanto ${ }^{2}$, Wayan Suana ${ }^{3}$ \\ ${ }^{1,2,3}$ Pendidikan Fisika, FKIP Universitas Lampung, Jl. S. Brojonegoro No.1 Bandar Lampung, Indonesia \\ e-mail: ${ }^{1}$ witripuspitasari0403@gmail.com
}

Diterima: 13 Juli 2017. Disetujui: 5 Oktober 2017. Dipublikasikan: 28 Oktober 2017

\begin{abstract}
Abstrak: Penelitian ini bertujuan untuk mengungkap pemahaman konseptual tentang vector, siswa kelas XI SMA di Kabupaten Natar, Lampung Selatan. Populasi adalah seluruh siswa kelas XI SMA dari tujuh SMA dan jumlah sampel sebanyak 167 siswa. Data dikumpulkan dengan menggunakan 15 soal pilihan jamak dan alasan pertanyaan yang dibutuhkan. Hasil penelitian menunjukkan bahwa hanya 39,1\% siswa yang mengerti tentang konsep vektor. Vektor satuan adalah subtopik yang paling mudah dipahami dimana $61,1 \%$ siswa memahami subtopik sedangkan arah vektor adalah subtopik yang paling sulit bagi siswa dimana hanya $23,3 \%$ yang mengerti subtopic.
\end{abstract}

Kata kunci: analisis konsep vektor, pemahaman konsep, siswa SMA.

\section{VECTORS CONCEPTS UNDERSTANDING ANALYSIS ON JUNIOR HIGH SCHOOL STUDENTS}

\begin{abstract}
This research aims to reveal the students' conceptual understanding about the vector of XI grade senior high school students in Natar district, South Lampung. The population was all of the students of XI grade from seven high schools, and the number of samples was 167 students. The data collected by using 15 multiple choice and reasons required questions. The results showed that only 39.1\% students understood about vector concept. Unit vector was the most understandable subtopic where $61.1 \%$ of students understand the subtopic whereas the direction of the vector was the most challenging subtopic for students where only $23.3 \%$ understand the subtopic.
\end{abstract}

(C) 2017 Pendidikan Fisika, FTK UIN Raden Intan Lampung

Keywords: vector concept analysis, concept understanding, high school students.

\section{PENDAHULUAN}

Fisika merupakan salah satu mata pelajaran dalam rumpun sains yang sangat erat kaitannya dengan kehidupan seharihari (Saregar, 2016). Fisika memaparkan tentang fenomena alam yang berbentuk fisik yang membutuhkan pemahaman tingkat tinggi yang komprehensif (Sasmita, 2017; Susiharti \& Ismet, n.d.).

Tujuan pembelajaran fisika pada hakikatnya adalah untuk mengantarkan pemahaman siswa menguasai konsepkonsep dan keterkaitannya untuk dapat memecahkan masalah terkait dalam kehidupan sehari-hari (Yuwarti, Pasaribu, \& Hatibe, n.d.). Siswa dikatakan paham apabila mereka dapat mengkonstruksi makna dari pesan-pesan pembelajaran, baik yang bersifat lisan, tulisan ataupun grafis, yang disampaikan melalui pengajaran, buku, atau layar computer (Irwandani \& Rofiah, 2015).

Kurangnya penguasaan konsep, lemahnya keterampilan siswa dalam berhitung, serta anggapan bahwa fisika adalah pelajaran yang sulit menjadi faktor yang menyebabkan rendahnya hasil belajar fisika siswa di sekolah (Mustari, 2015; Pujianto, Nurjannah, \& Darmadi, n.d.; Rhahim, Tandililing, \& Mursyid, n.d.). Berbagai gejala yang tampak pada proses pembelajaran seperti: siswa kurang mau bertanya, enggan menjawab pertanyaan guru, kurang mampu 
menjelaskan, kurang bersemangat dalam belajar, pasif dalam diskusi (Erlinda, 2017).

Kesulitan memahami konsep-konsep fisika yang dialami oleh siswa bukan hanya karena faktor materi yang disampaikan, tetapi juga karena kurang tepatnya model pembelajaran yang dilakukan oleh guru sehingga siswa kurang dilibatkan dalam proses belajar mengajar (Gumrowi, 2016; Komikesari, 2016; Poniman, 2016; Yusuf \& Amin, 2016). Padahal, untuk menguasai fisika, siswa dituntut untuk aktif dalam kegiatan belajar mengajar.

Salah satu materi yang harus dikuasai siswa dengan baik didalam pembelajaran fisika adalah vektor. Vektor memiliki peranan penting dalam banyak cabang fisika (Bollen, Kampen, Baily, Kelly, \& Cock, 2017; Sirait \& Oktavianty, 2017). Sebagian besar konsep fisika yang tercakup dalam mata kuliah fisika pengantar ditingkat universitas diwakili oleh vektor (Barniol \& Zavala, 2014). Vektor merupakan sebuah konsep dalam pelajaran fisika yang berkaitan dengan materi lain seperti gerak, gaya, momentum, impuls, dan lain-lain (Bollen, Kampen, \& Cock, 2015; Yuwarti et al., n.d.).

Berdasarkan studi pendahuluan di salah satu SMA Negeri di kota Palu, diperoleh hasil bahwa pemahaman konsep vektor kinematika yang diberikan kepada 6 orang siswa kelas XII masih dalam kategori rendah. Kesulitan terbesar yang dihadapi siswa ialah mengekstrapolasi mencakup konsep persamaan vektor posisi, percepatan sesaat, dan percepatan rata-rata (Yuwarti et al., n.d.). Melihat hasil studi pendahuluan tersebut, diketahui bahwa masih terdapat banyak permasalahan yang dihadapi siswa dalam memahami konsep vektor. Oleh karena itu peneliti tertarik untuk melakukan penelitian tentang pemahaman konsep vektor pada siswa di salah satu SMA
Negeri di Kecamatan Natar, Lampung Selatan.

\section{METODE PENELITIAN}

Penelitian ini merupakan jenis penelitian kuantitatif dengan pendekatan deskriptif. Populasi pada penelitian ini ialah seluruh siswa kelas XI IPA di 7 SMA di Kecamatan Natar. Sampel pada penelitian ini dilakukan di 4 SMA di Kecamatan Natar antara lain SMA Negeri 1 Natar, SMA Negeri 2 Natar, SMA Swadhipa Natar, dan SMA Tri Sukses Natar dengan sampel berjumlah 167 orang siswa.

Instrumen penelitian yang digunakan berupa soal pilihan jamak disertai alasan menjawab. Jumlah soal yang diujikan sebanyak 15 soal dengan 5 pilihan jawaban beserta alasan menjawab. Instrumen soal yang diujikan ini beberapa mengacu pada contoh instrumen soal dari (Barniol \& Zavala, 2014; Heckler \& Scaife, 2015; Wang \& Sayre, 2010; Zavala \& Barniol, 2010). Materi vektor yang akan diujikan di kelompokkan menjadi 6 subtopik antara lain: menentukan notasi dan besar vektor, menentukan vektor satuan, menghitung komponen pada vektor, menentukan penjumlahan dan pengurangan vektor, menentukan arah vektor, menghitung vektor dengan perkalian skalar dan perkalian titik. Tingkat persentase pemahaman dikelompokkan menjadi beberapa kategori seperti terlihat pada Tabel 1. Selanjutnya untuk mengetahui kriteria jawaban siswa paham konsep, siswa menebak dan siswa tidak paham konsep pada jawaban dapat di lihat pada Tabel 2.

Tabel 1. Persentase Tingkat Pemahaman

\begin{tabular}{lll}
\hline No & Persentase & \multicolumn{1}{c}{ Kategori } \\
\hline 1 & $\leq 30 \%$ & Rendah \\
2 & $30 \leq x 60 \%$ & Sedang \\
3 & $61-100 \%$ & Tinggi \\
\hline
\end{tabular}


Tabel 2. Kriteria untuk Paham Konsep, Menebak, dan Tidak Paham Konsep

\begin{tabular}{cccc}
\hline No & Soal & Jawaban & Kategori \\
\hline \multirow{2}{*}{1} & Pilihan & Benar & Paham \\
& Jamak & & Konsep \\
& Alasan & Benar & \\
& Pilihan & Benar & Menebak \\
2 & Jamak & Benar & \\
& Alasan & Benar & \\
& Pilihan & Benebak \\
3 & Jamak & Benar & \\
& Alasan & Benar & Tidak \\
& Pilihan & Benar & Paham \\
4 & Jamak & Kenar & Konsep \\
& Alasan & Benar
\end{tabular}

\section{HASIL DAN PEMBAHASAN}

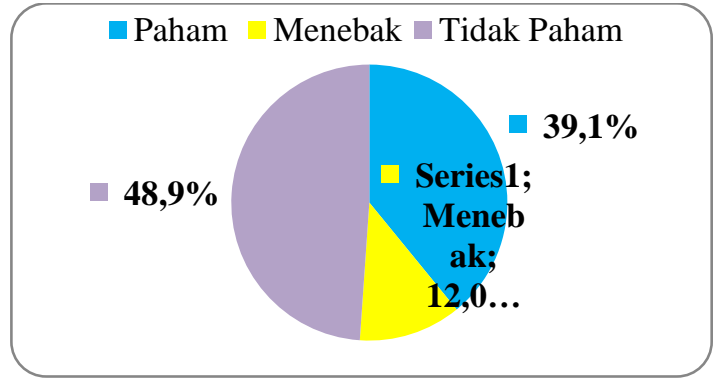

Gambar 1. Persentase Pemahaman Konsep Siswa

Hasil penelitian menunjukkan bahwa pemahaman konsep siswa terhadap materi vektor masuk dalam kategori sedang. Dari 167 orang siswa, persentase siswa yang paham konsep sebesar 39,1\%, persentase rata- rata siswa yang menebak sebesar $12 \%$ dan tidak paham konsep sebesar
48,9\%. Hasil tersebut dapat dilihat pada Gambar 1.

Kategori pemahaman konsep vektor per subtopik ditunjukkan pada Gambar 2. Pada gambar terlihat bahwa subtopik yang paling banyak terdapat siswa kategori paham konsep berada pada subtopik menentukan vektor satuan dengan persentase sebesar $61,1 \%$, sedangkan untuk subtopik paling sedikit kategori siswa paham konsep ialah subtopik menentukan arah vektor dengan persentase sebesar 23,3\%.

Kategori menebak paling banyak terdapat pada subtopik menentukan notasi dan besar pada vektor dengan persentase siswa menebak sebesar $16 \%$, sedangkan paling sedikit siswa menebak terdapat pada subtopik menghitung vektor dengan perkalian skalar dan perkalian titik dengan persentase sebesar 3,9\%.

Kategori tidak paham paling banyak berada pada subtopik menentukan arah vektor dengan persentase sebesar $68,6 \%$, nilai ini hampir sama dengan subtopik menghitung vektor dengan menggunakan perkalian skalar dan perkalian titik yang memiliki nilai persentase siswa tidak paham konsep sebesar 68\%, sedangkan untuk subtopik yang lain, rata - rata persentase tidak paham siswa di bawah $60 \%$ seperti terlihat pada Gambar 2.

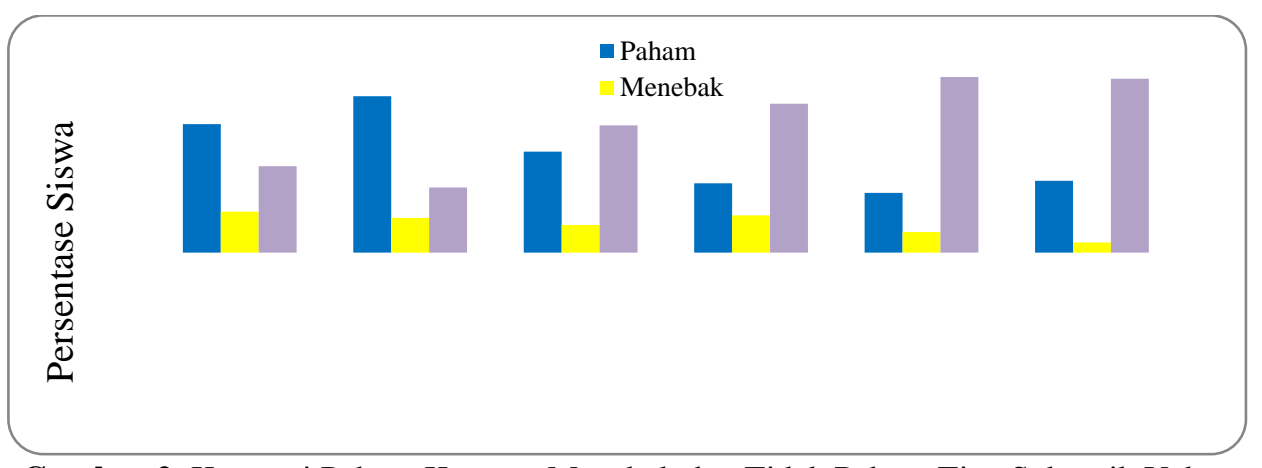

Gambar 2. Kategori Paham Konsep, Menebak dan Tidak Paham Tiap Subtopik Vektor 


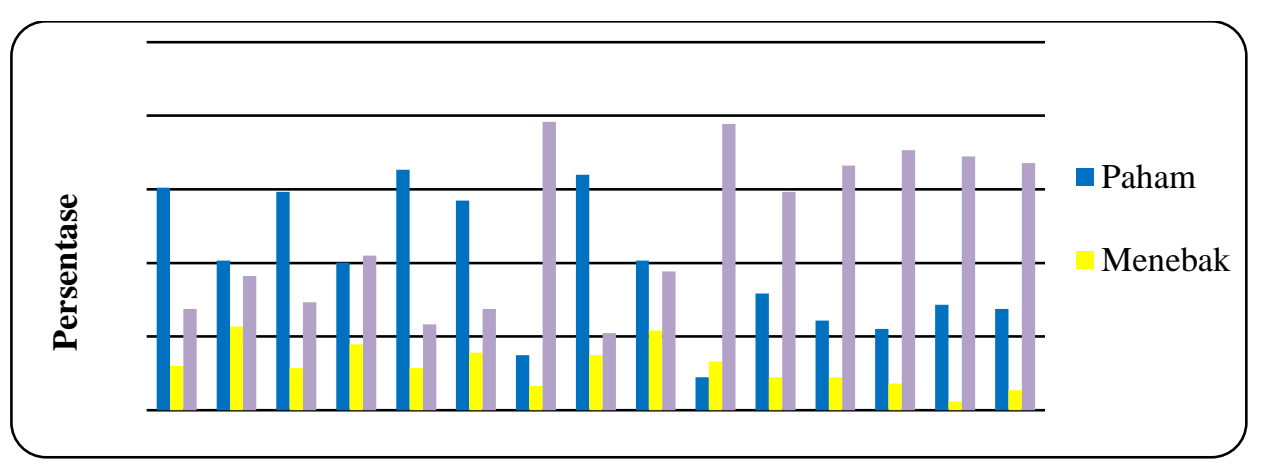

Gambar 3. Distribusi Pemahaman Konsep Tiap Nomor Soal.

Gambar 3 terlihat bahwa item soal dengan tingkat kesulitan rendah ada pada soal nomor $1,3,5,6$, dan 8 . Item soal dengan tingkat kesulitan sedang ada pada nomor 2, 4, 9 dan 11. Item soal dengan tingkat kesulitan tinggi berada pada soal nomor 7 (besar vektor dalam sumbu $\mathrm{x}$ dan y), soal nomor 10 (menghitung resultan dari ketiga vektor), soal nomor 12 (menentukan arah vektor yang tepat), soal nomor 13 (menentukan arah vektor yang sama), soal nomor 14 (menghitung perkalian $\mathrm{A} \cdot \mathrm{B}$ ) dan terakhir soal nomor 15 (menghitung perkalian silang $\mathrm{A} \times \mathrm{B}$ ).

Berdasarkan hasil dari soal yang diujikan, jumlah siswa paham konsep paling banyak terdapat pada soal nomor 5 dengan persentase sebesar $65,3 \%$ kemudian soal nomor 8 dengan persentase $64 \%$, sedangkan untuk kategori menebak paling banyak berada pada nomor 9 dengan persentase sebesar $21,6 \%$ dan nomor 2 dengan persentase sebesar $22,8 \%$. Untuk kategori siswa yang tidak paham konsep paling banyak berada pada soal nomor 7 dengan persentase sebesar
$78,4 \%$ dan soal nomor 10 dengan persentase sebesar $77,8 \%$.

Penjelasan dari setiap subtopik akan dijelaskan sebagai berikut ini:

(1) Menentukan Notasi dan Besar pada Vektor

Persentase rata-rata siswa paham konsep pada subtopik menentukan notasi dan besar pada vektor ialah 50,2\%, Subtopik ini berada pada nomor 1,2,3 dan 4. Siswa yang paling banyak tidak paham konsep terdapat pada soal nomor 4, sedangkan untuk soal nomor 1, 2 dan 3 persentase siswa tidak paham konsep relatif dibawah $40 \%$.

Soal nomor 4 mengenai menentukan vektor yang mempunyai nilai yang sama dengan vektor $\vec{a}$ memiliki persentase siswa tidak paham konsep sebesar $42 \%$, seperti terlihat pada Gambar 4. Siswa tidak paham, karena siswa tidak menghitung kotak pada vektor $\vec{a}$ melainkan siswa hanya melihat arah yang sama yang ditunjukan vektor $\vec{a}$

Perhatikan vektor - vektor dibawah ini. Manakah vektor yang memiliki nilai atau besar yang sama dengan vektor $\vec{a}$ adalah ...

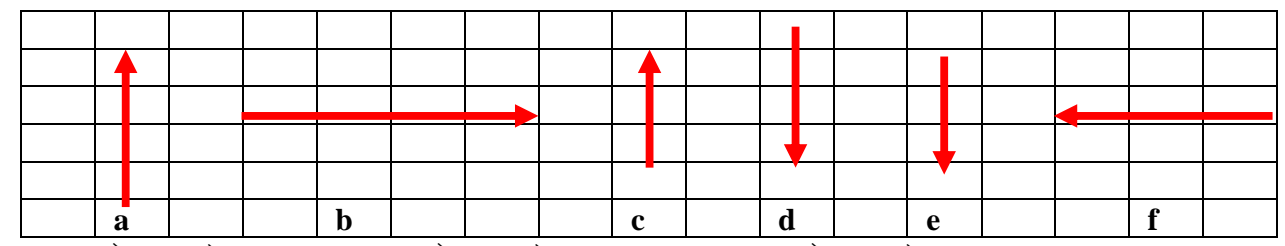
a. $|\vec{D}|$ dan $|\vec{F}|$
b. $|\vec{C}|$ dan $|\vec{B}|$
d. $|\vec{D}|$ dan $|\vec{E}|$
e. $|\vec{B}|$ dan $|\vec{D}|$
c. $|\vec{E}|$ dan $|\vec{F}|$

Gambar 4. Soal Nomor 4 Yang Diujikan 
(2) Menentukan Vektor Satuan

Subtopik menentukan vektor satuan berada pada soal nomor 5 dan 6 . Untuk soal nomor 5 dan 6 , persentase siswa tidak paham adalah di bawah $30 \%$. Jumlah persentase siswa paham konsep paling besar terdapat pada soal nomor 5 dengan persentase sebesar 65,3\%. Kemudian dapat dilihat pada Gambar 5, siswa yang tidak memahami konsep untuk soal nomor 5 dikarenakan siswa tidak bisa membaca vektor pada gambar, siswa hanya melihat ada berapa kotak pada gambar lalu untuk menentukan garis $\hat{\imath},-\hat{\imath}$, $\hat{\jmath}$ dan $-\hat{\jmath}$ mereka menentukan dengan sembarangan.

(3) Menghitung Komponen Vektor

Subtopik menghitung komponen vektor berada pada nomor 7 dan 8 . Siswa yang paling banyak tidak paham konsep berada pada soal nomor 7 dengan persentase sebesar $78,4 \%$. Soal nomor 7 mengenai menghitung besar vektor dalam sumbu $x$ dan sumbu $y$. Seperti yang ditampilkan pada Gambar 6, banyak siswa tidak memahami konsep karena siswa tidak mengingat persamaan apa yang akan digunakan untuk menghitung sumbu $x$ dan sumbu $y$.

Berdasarkan hasil penelitian yang telah dilakukan oleh Soge, menunjukkan bahwa pemahaman konsep pada subtopik komponen vektor ini masih rendah, hal ini ditunjukkan dari hasil persentase pemahaman siswa yang berada dibawah $30 \%$ yakni hanya sebesar $11,3 \%$. Miskonsepsi sebesar 10\%, kurang paham sebesar $41,3 \%$ dan tidak paham atau menebak sebesar 37,3\% (Soge, 2016).

Tentukan vektor - vektor di bawah ini dalam ungkapan vektor satuan!

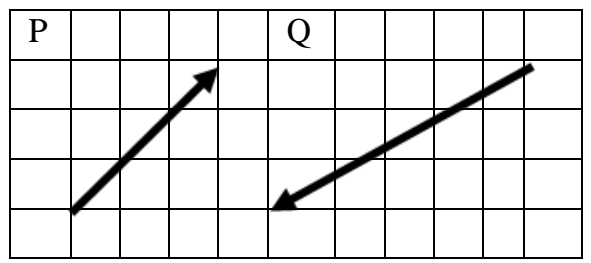
a. $|\vec{P}|=2 \hat{\imath}-3 \hat{\jmath}$ dan $|\vec{Q}|=-3 \hat{\imath}+3 \hat{\jmath}$
d. $|\vec{P}|=-2 \hat{\imath}-3 \hat{\jmath}$ dan $|\vec{Q}|=-3 \hat{\imath}-3 \hat{\jmath}$
b. $|\vec{P}|=2 \hat{\imath}+3 \hat{\jmath}$ dan $|\vec{Q}|=-3 \hat{\imath}-3 \hat{\jmath}$
e. $|\vec{P}|=2 \hat{\imath}+3 \hat{\jmath}$ dan $|\vec{Q}|=3 \hat{\imath}-3 \hat{\jmath}$
c. $|\vec{P}|=-2 \hat{\imath}+3 \hat{\jmath}$ dan $|\vec{Q}|=3 \hat{\imath}+3 \hat{\jmath}$

Gambar 5. Soal Nomor 5 Yang Diujikan.

Jika besar vektor $\overrightarrow{\mathrm{A}}=30$ satuan membentuk sudut $30^{\circ}$ terhadap sumbu $x$ positif. Nilai komponen vektor tersebut dalam sumbu $x$ dan sumbu $y$ adalah ....
a. $\mathrm{A} x=10$ satuan dan $\mathrm{A} y=20$ satuan
d. $A x=20$ satuan dan $A y=10$ satuan
b. $A x=15$ satuan dan $A y=15 \sqrt{3}$ satuan
e. $A x=15 \sqrt{3}$ dan $A y=15$ satuan
c. $\mathrm{A} x=15$ satuan dan $\mathrm{A} y=20$ satuan

Gambar 6. Soal Nomor 7 Yang Diujikan

(4) Menentukan Penjumlahan serta Pengurangan Vektor

Subtopic untuk menentukan penjumlahan dan pengurangan vektor berada pada nomor 9, 10 dan 11 . Persentase siswa paling banyak tidak paham konsep untuk penjumlahan vektor berada pada soal nomor 10 dengan 
persentase sebesar 77,8\%, sedangkan untuk nomor 9 sebesar $37,7 \%$.

Soal nomor 10 mengenai penjumlahan resultan dari ketiga vektor seperti yang ditampilkan pada Gambar 7, siswa tidak paham karena mereka tidak mengingat persamaan yang digunakan untuk mencari nilai resultan dari ketiga vektor $\overrightarrow{\mathrm{F}}_{1} \overrightarrow{\mathrm{F}}_{2} \overrightarrow{\mathrm{F}}_{3}$ dan siswa lupa dalam menentukan garis yang akan membedakan antara garis sumbu $x,-x, y$ dan sumbu $-y$. Hal ini berarti pemahaman konsep siswa untuk subtopik menentukan penjumlahan vektor ini rendah.
Hal ini sejalan dengan penelitian yang telah dilakukan oleh Susiharti dan Ismet yang menyatakan bahwa dari 29 orang siswa subjek penelitian, hanya 1 siswa $(3,4 \%)$ saja yang menjawab benar. Sebagian besar siswa tidak mampu dalam menyelesaikan soal penjumlahan vektor secara analitis disebabkan karena siswa tidak dapat menggambarkan penguraian semua vektor ke dalam komponennya. Siswa tidak mampu menggambarkan penguraian vektor dengan lengkap, sehingga tidak bisa ketahap penjumlahan searah sumbu- $x$ dan sumbu- $y$ (Susiharti\& Ismet, 2017).

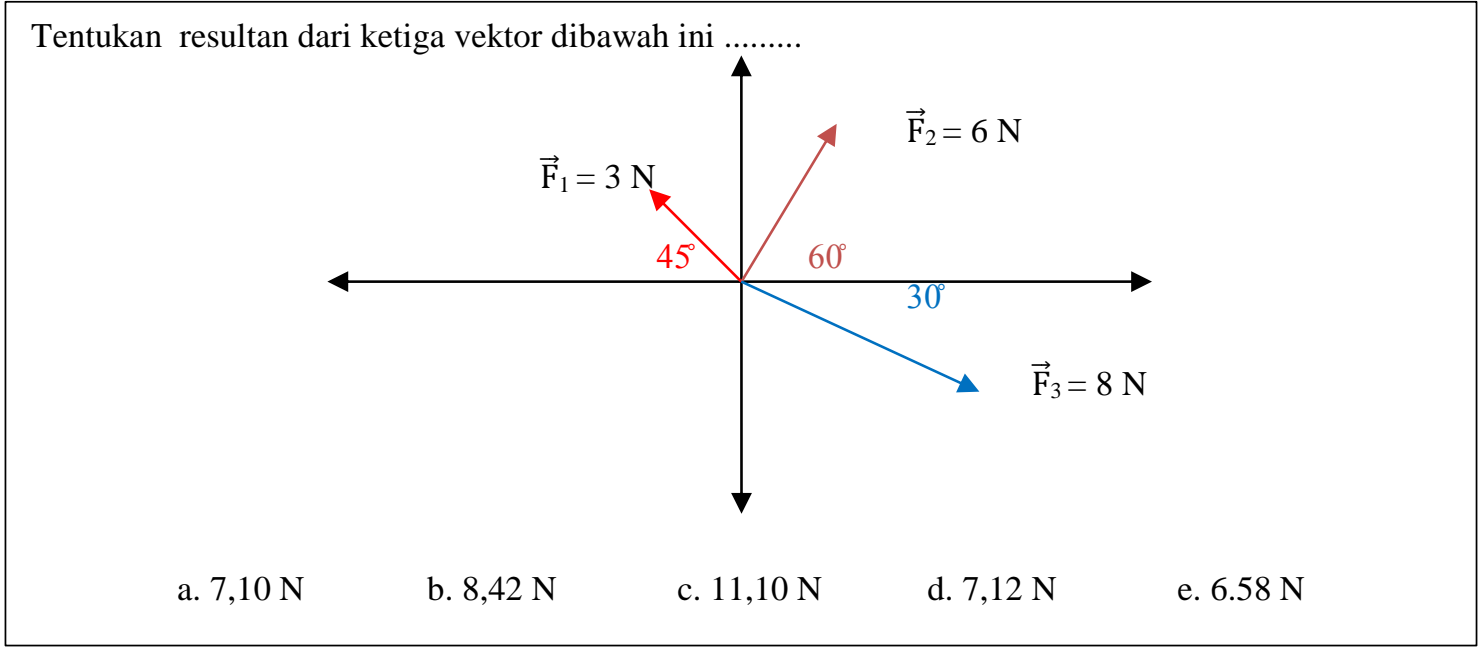

Gambar 7. Soal Nomor 10 Yang Diujikan

Tentukan gambar dibawah ini yang menyatakan $\vec{R}=\vec{M}-\vec{N}$
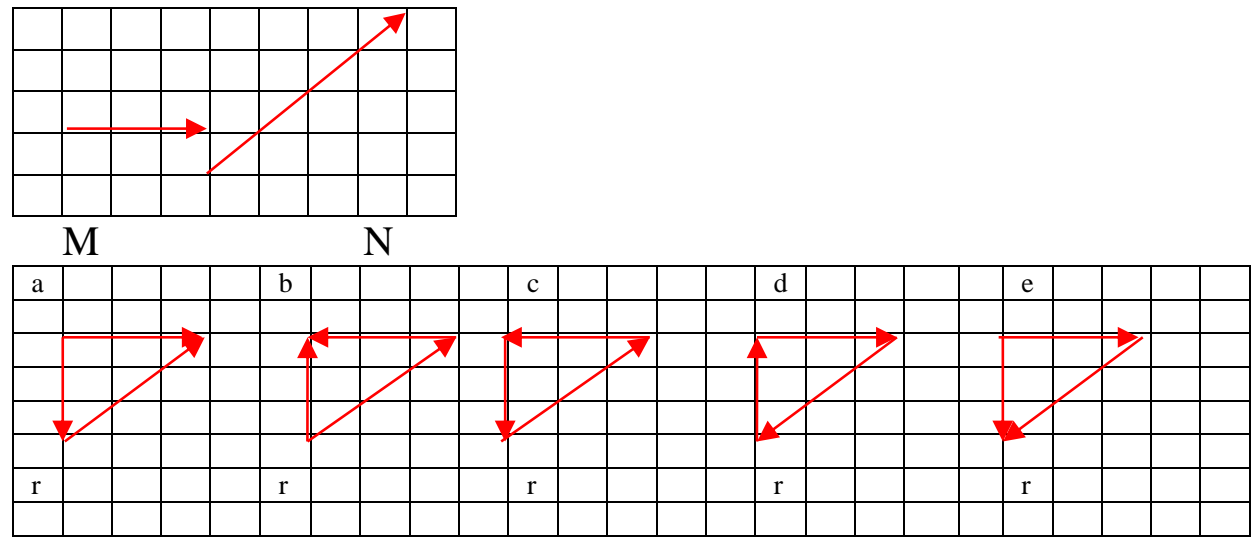

Gambar 8. Soal Nomor 11 Yang diujikan 
Soal nomor 11 mengenai pengurangan pada vektor dengan persentase tidak paham siswa sebesar 59,3\% Gambar 8 . Jawaban siswa " Dijumlahkan seperti biasa bu dan untuk menetukan resultan dilihat saja ekor dengan ekornya". Dari kutipan jawaban siswa, terlihat bahwa siswa tidak paham terhadap soal. Siswa yang tidak paham konsep dikarenakan siswa berpikir bahwa nilai $\vec{M}-\vec{N}$ di hubungkan sama dengan cara pada penjumlahan, karena nilai vektor $\overrightarrow{\mathrm{N}}$ maka seharusnya vektor $\vec{N}$ arahnyaSoal nomor 11 mengenai pengurangan pada vektor dengan persentase tidak paham siswa sebesar 59,3\% Gambar 8. Jawaban siswa " Dijumlahkan seperti biasa bu dan untuk menetukan resultan dilihat saja ekor dengan ekornya". Dari kutipan jawaban siswa, terlihat bahwa siswa tidak paham terhadap soal. Siswa yang tidak paham konsep dikarenakan siswa berpikir bahwa nilai $\overrightarrow{\mathrm{M}}-\overrightarrow{\mathrm{N}}$ di hubungkan sama dengan cara pada penjumlahan, karena nilai vektor $\vec{N}$ maka seharusnya vektor $\vec{N}$ arahnya dibalik dan siswa tidak mengetahui bahwa arah vektor $\overrightarrow{\mathrm{N}}$ dibalik.

Hal ini didukung oleh hasil penelitian yang yang telah dilakukan oleh Affandi menyatakan bahwa dari 27 orang siswa sebagai sampel penelitian sebanyak 7 siswa $(26,9 \%)$ mengalami kesalahan dan sebagian besar siswa belum mengetahui konsep dasar dari pengurangan vektor. Siswa belum bisa memberikan alasan yang tepat mengapa vektor resultan yang dihasilkan menjadi seperti itu.

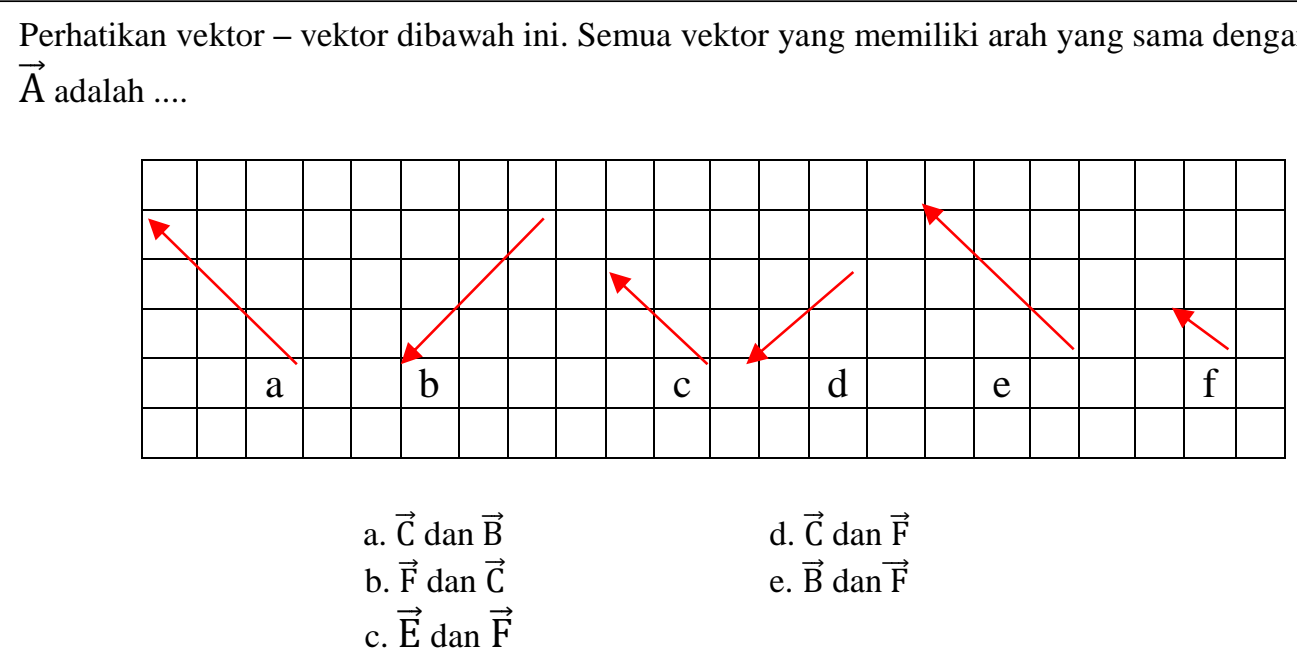

Gambar 9. Soal Nomor 13 yang diujikan

(5). Menentukan Arah Vektor

Subtopic mengenai arah vektor tepatnya pada nomor 12 dan 13. Soal nomor 12 mengenai menentukan vektor arah pada 3 buah vektor dengan persentase tidak memahami konsep yaitu sebesar $66,5 \%$.

Soal nomor 13 mengenai vektor yang memiliki arah yang sama dengan vektor $\vec{a}$ dengan persentase tidak paham konsep yaitu sebesar 70,7\% Gambar 9. Siswa yang tidak paham konsep dikarenakan siswa hanya mencari arah vektor lainnya yang sama dengan vektor arah $\vec{a}$. Padahal untuk menentukan vektor mana yang sama dengan arah vektor $\vec{a}$ bukan hanya dilihat arahnya kemana namun harus berada dalam satu garis.

Penelitian yang yang dilakukan oleh (Sukadi, 2016) menunjukkan bahwa sebanyak 19 orang mahasiswa $(52,8 \%)$ kesalahan yang paling banyak dilakukan ialah kesalahan menggunakan konsep, mahasiswa tidak dapat menentukan arah 
dalam menggambarkan besar vektor. Hal ini dapat di artikan bahwa mahasiswa yang sudah satu tingkat diatas siswa SMA, dalam mengerjakan soal subtopik arah vektor pun masih banyak yang mengalami kesalahan konsep.

(6). Menghitung Vektor Perkalian Skalar dan Perkalian Titik

Subtopic menghitung vektor dengan perkalian skalar dan perkalian titik berada pada nomor 14 dan 15 . Soal nomor 14 menghitung perkalian A $-\mathrm{B}$ persentase siswa tidak paham konsep sebesar $68,9 \%$ Gambar 10. Siswa tidak paham konsep karena siswa tidak mengingat persamaan yang akan digunakan untuk menghitung dan ada sebagian siswa yang terbalik menggunakan persamaan, mereka menggunakan persamaan untuk mencari $\mathrm{A} \times \mathrm{B}$.

Soal nomor 15 mengenai hasil dariperkalian $\mathrm{A} \times \mathrm{B}$ dengan persentase siswa yang tidak paham konsep sebesar
67,1\%Gambar 11. Siswa yang tidak paham konsep dikarenakansiswa tidak mengingat persamaan yang akan digunakan untuk menghitung perkalian $\mathrm{A} \times \mathrm{B}$, seringkali dari jawaban siswa mereka bingung menggunakan persamaan yang mana yang akan di gunakan sehingga, persamaan yang digunakan terbalik dengan A • B.

Hasil penelitian yang telah dilakukan oleh (Soge, 2016) menunjukkan hasil penelitian bahwa pemahaman konsep siswa terhadap sub konsep menghitung hasil perkalian titik dan hasil perkalian silang vektor dinilai masih sangat rendah, hal ini ditunjukkan dengan hasil persentase pemahaman siswa yang berada dibawah $30 \%$ yakni sebesar $11 \%$. Analisa lebih lanjut didaptkan hasil bahwa miskonsepsi sebesar $10 \%$ kurang paham sebesar $47,5 \%$ dan yang tidak paham konsep atau menebak sebesar $31 \%$.

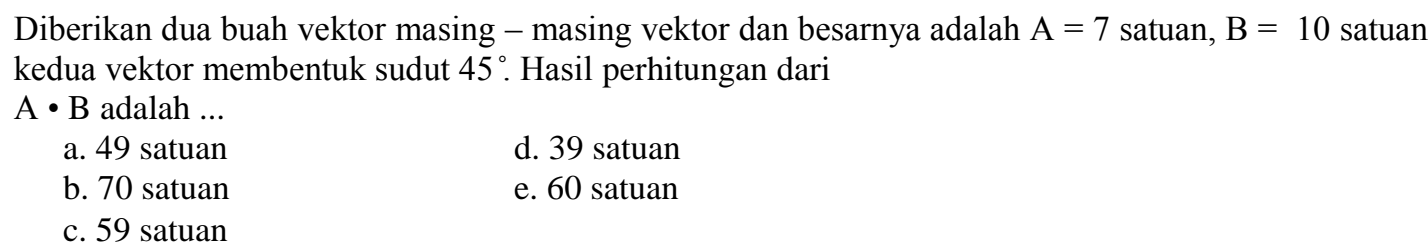

Gambar 10. Soal Nomor 14 yang diujikan

Dua buah vektor masing-masing vektor besarnya adalah $A=8$ satuan, $B=10$ satuan. Kedua vektor ini membentuk sudut 37 . Tentukan hasil dari A x B ... .
a. 49 satuan
d. 40 satuan
b. 48 satuan
e. 30 satuan
c. 52 satuan

Gambar 11. Soal Nomor 15 yang diujikan

\section{SIMPULAN DAN SARAN}

\section{Simpulan}

Pemahaman konsep vektor siswa SMA kelas XI IPA di Kecamatan Natar terhadap materi vektor dinilai sedang, hal ini dapat dilihat dari persentase hasil pemahaman konsep siswa yang diatas $30 \%$ yakni sebesar 39,1\%. Analisa lanjut didapatkan bahwa menebak sebesar $12 \%$, dan tidak memahami konsep sebesar $48,9 \%$.

Untuk pemahaman setiap subtopik konsep vektor, Siswa cukup banyak memahami pada subtopik menentukan vektor satuan persentase menunjukkan bahwa sebesar $61,1 \%$ siswa paham konsep, untuk subtopik pemahaman 
konsep yang sedikit siswa memahaminya yaitu subtopik menentukan arah vektor dengan persentase pemahaman konsep menunjukkan sebesar $23,3 \%$ siswa yang paham konsep.

\section{Saran}

Penelitian selanjutnya diharapkan peneliti untuk mengkaji lebih dalam mengenai apa saja faktor-faktor yang menyebabkan siswa SMA Kelas XI

\section{DAFTAR PUSTAKA}

Barniol, P., \& Zavala, G. (2014). Test of understanding of vectors: A reliable multiple-choice vector concept test. Physical Review Special Topics Physics Education Research, 10(1), $1-14$. https://doi.org/10.1103/PhysRevSTP ER.10.010121

Bollen, L., Kampen, P. Van, Baily, C., Kelly, M., \& Cock, M. De. (2017). Student difficulties regarding symbolic and graphical representations of vector fields. Physical Review Physics Education Research, 13(20109), 1-17. https://doi.org/10.1103/PhysRevPhys EducRes.13.020109

Bollen, L., Kampen, P. Van, \& Cock, M. De. (2015). Students, difficulties with vector calculus in electrodynamics, 20129, 1-14. https://doi.org/10.1103/PhysRevSTP ER.11.020129

Erlinda, N. (2017). Peningkatan Aktivitas dan Hasil Belajar Siswa melalui Model Kooperatif Tipe Team Game Tournament pada Mata Pelajaran Fisika di SMK. Jurnal Keguruan Dan Ilmu Tarbiyah, 2(1), 47-52. https://doi.org/10.24042/tadris.v2i1.1 738

Gumrowi, A. (2016). Strategi Pembelajaran melalui Pendekatan Kontekstual dengan Cooperative Learning untuk Meningkatkan Hasil
IPAtidak memahami konsep materi vektor, serta penelitian selanjutnya diharapkan mengkaji lebih lanjut mengenai kaitan lemahnya pemahaman konsep vektor untuk konsep fisika yang lainnya yang banyak menggunakan pemahaman konsep vektor apakah terdapat pengaruh bahwa lemahnya konsep vektor dapat mempengaruhi dalam mempelajari konsep fisika lainnya.

Belajar Gelombang Siswa Kelas XII MAN 1 Bandar Lampung. Jurnal Ilmiah Pendidikan Fisika Al-Biruni, 5(2), 183-191. https://doi.org/10.24042/jpifalbiruni. v5i2.118

Heckler, A. F., \& Scaife, T. M. (2015). Adding and Subtracting Vectors : the Problem with the Arrow Representation, 10101(11), 1-17. https://doi.org/10.1103/PhysRevSTP ER.11.010101

Irwandani, \& Rofiah, S. (2015). Pengaruh Model Pembelajaran Generatif Terhadap Pemahaman Konsep Fisika Pokok Bahasan Bunyi Peserta Didik MTs Al-Hikmah Bandar Lampung. Jurnal Ilmiah Pendidikan Fisika AlBiruni, 4(2), 165-177. https://doi.org/10.24042/jpifalbiruni. v4i2.90

Komikesari, H. (2016). Peningkatan Keterampilan Proses Sains dan Hasil Belajar Fisika Siswa pada Model Pembelajaran Kooperatif Tipe Student Team Achievement Division. Jurnal Keguruan Dan Ilmu Tarbiyah, 1(1), 15-22.

Mustari, M. (2015). Pengaruh Penggunaan Media Gambar Lewat Komputer terhadap Hasil Belajar Fisika pada Siswa Kelas X SMA Negeri 3 Makassar. Jurnal Ilmiah Pendidikan Fisika Al-BiRuNi, 4(2), 269-280.

Poniman. (2016). Upaya Peningkatan 
Aktivitas dan Hasil Belajar Fisika dengan Metode Praktikum pada Siswa Kelas XI IPA MAN 1 Kalianda Lampung Selatan. Jurnal Ilmiah Pendidikan Fisika Al-Biruni, 5(2), 257-264.

Pujianto, A., Nurjannah, \& Darmadi, I. W. (n.d.). Analisis Konsepsi Siswa Pada Konsep Kinematika Gerak Lurus. Jurnal Pendidikan Fisika Tadulako (JPFT), 1(1), 16-21.

Rhahim, E., Tandililing, E., \& Mursyid, S. (n.d.). Hubungan keterampilan matematika dengan kemampuan menyelesaikan soal fisika terhadap miskonsepsi siswa pada impuls momentum, (2002), 1-9.

Saregar, A. (2016). Pembelajaran Pengantar Fisika Kuantum Dengan Memanfaatkan Media Phet Simulation Dan Lkm Melalui Pendekatan Saintifik: Dampak Pada Minat Dan Penguasaan Konsep Mahasiswa. Jurnal Ilmiah Pendidikan Fisika Al-Biruni, 5(1), 53-60.

Sasmita, P. R. (2017). Penerapan metode inkuiri terbimbing menggunakan media kit fisika: upaya meningkatkan aktivitas dan hasil belajar fisika siswa. Jurnal Ilmiah Pendidikan Fisika Al-Biruni, 6(1), 95-102.

Sirait, J. H., \& Oktavianty, E. (2017). Analysis of Pre-Service Physics Teachers ' Understanding of Vectors and Forces. Journal of Turkish Science Education, 14(2), 82-95. https://doi.org/10.12973/tused.10200 a

Susiharti, \& Ismet. (n.d.). Studi Kesalahan Siswa dalam Menyelesaikan SoalSoal Vektor di SMA Negeri 1 Inderalaya. Jurnal Inovasi Dan Pembelajaran Fisika, 99-105.

Wang, T., \& Sayre, E. C. (2010). Maximum likelihood estimation (MLE) of students' understanding of vector subtraction. In AIP Conference Proceedings (Vol. 1289, pp. 329-332). American Institute of Physics. https://doi.org/10.1063/1.3515236

Yusuf, M. T., \& Amin, M. (2016). Pengaruh Mind Map dan Gaya Belajar terhadap Hasil Belajar Matematika Siswa. Tadris: Jurnal Keguruan Dan Ilmu Tarbiyah, 1(1), 85-92.

Yuwarti, Pasaribu, M., \& Hatibe, A. (n.d.). Analisis Pemahaman Konsep Siswa SMA Lab-School Palu pada Materi Hukum Newton. Jurnal Pendidikan Fisika Tadulako (JPFT), 5(3), 12-15.

Zavala, G., \& Barniol, P. (2010). Students' understanding of the concepts of vector components and vector products. In AIP Conference Proceedings (Vol. 1289, pp. 341344). American Institute of Physics. https://doi.org/10.1063/1.3515240 